\title{
On Alawization in Syria
}

\author{
Sobre Alauização na Síria
}

DOI: https://doi.org/10.22456/2178-8839. 113987

Gabriela Santos da Silva

Universidade Federal do Rio Grande do Sul, Porto Alegre, Brasil silva.gaabii@gmail.com

Silvia Regina Ferabolli Universidade Federal do Rio Grande do Sul, Porto Alegre, Brasil silvia.ferabolli@ufrgs.br

\begin{abstract}
This paper employs the term 'Alawization' to define the prominence of members of the Alawi community in positions of power across Syria, a process that has already been noticed by some scholars, but that has not been named until now. We intend to answer the following ques tions: is there a process that can be called Alawization happening in Syria? How could Alawization have become a political process in the country? How could this have evolved over time? And how is it perceived among practitioners of international relations? Essentially, the circumstances that could allow for this process to take place are embedded in Syria's colonial period and its evolution is closely related to the rise of Hafiz al-Assad to power - launching an "Assad dynasty", that continues ruling the country. Perception of this ongoing process was based, methodologically, on historical representations and was investigated through semi-structured interviews with diplomats based at the UN working with Middle Eastern issues and/or that have already been assigne d to posts in Syria. It concludes by suggesting that, albeit there's recognition of this process, there is still disagreement on how it occurs and how widespread it is internally.
\end{abstract}

Keywords: Syria; Alawization; Perception;

\section{Resumo}

Este artigo emprega o termo "Alauização" para definir a proeminência de membros da comunidade alauíta em posições de poder na Síria, um processo que já foi notado por alguns estudiosos, mas que não foi nomeado até agora. Pretendemos responder as seguintes perguntas: existe um processo que pode ser chamado de Alauização acontecendo na Síria? Como a Alauização pode ter se tornado um processo político no país? Como ela pode ter evoluíd o com o tempo? E como ela é percebida entre os profissionais de relações internacionais? Essencialmente, as circunstâncias que poderiam permitir que esse processo ocorresse estão enraizadas no período colonial da Síria e sua evolução está intimamente relacionada à ascensão de Hafiz al-Assad ao poder lançando uma "dinastia Assad", que continua governando o país. A percepção desse processo baseou-se, metodologica mente, na representação histórica e foi investigada por meio de entrevistas semiestruturadas com diplomatas sediados na ONU que trabalham com questões do Orien te Médio e/ou que já ocuparam cargos na Síria. Conclui-se sugerindo que, embora haja o reconhecimento desse processo, ainda há desacordo sobre como ele ocorre e quão disseminado é internamente.

Palavras-chave: Síria; Alauização; Percepção;

Received: May14, 2021

Accepted: September 29, 2021 


\section{Introduction}

"I don't believe in witches, but that they exist, they exist". This old Castilian popular saying, often attributed to Miguel de Cervantes, is used to give rational meaning to subjective, and oftentimes illogical, events and phenomena. In Syria, the "witches" can be found in the way politics are organized.

After the seizure of power by the Ba'ath Party, in 1963, the country's political, economic, social, and security sectors suffered drastic changes. Of the fifteen members of the Ba'athist MilitaryCommittee that took over Syria's day -today affairs, five were Alawis - and three of them, Hafiz al-Assad, Salah Jadid and Muhammad 'Umran, held the highest leadership posts. The coup d'état led to a dismissal of 700 Army officers, half of which were replaced by Alawis. Later on, following the Corrective Revolution that led Hafiz al -Assad to power in 1970, these ethnic shifts in leadership became even more apparent. Alawis started occupying positions in the military's intelligence community and as commanders of different forces. Between 1970 and 1997, of the 31 newlyappointed officers (all of whom Assad hand -picked) 19were Alawis (VAN DAM, 2017;2011; BATATU,1999).

This state of affairs has caused resentment among non-Alawis in Syria, whobelieved Alawis were unjustifiably favoured. Non-Alawis disapproved the rise of one region over another and of a community thus far considered inferior. "Yet, thanks to their strong position in the army, the security services, the professions, the party, and indeed in every institution across the land, the progress of Alawis seemed irreversible" (SEALE, 1995, p. 455). Alawi is a religious strand of Islam, which belonged until the nineth century to Shiism. It was a strand that until 1970 was considered secondary in Middle East-related studies, because it was a more isolationist group, impoverished and without much political influence within Syrian society. In Syria, about 75\% of the individuals in this group lived in the northwest Latakia region, and most worked in the agricultural sector. The rise of an Alawi, Hafiz al-Assad, to the presidency in Syria brought visibility to the Alawis and made them a major focus of research, for being a ruling minority (VAN DAM, 2011; FRIEDMAN, 2010; ZISSER, 2001).

Based on this context presented by Seale's statement on the seemingly irreversible advance of Alawis in Syria, and in dialogue with the scholarship focused on Syrian politics, a window of investigation opens up to scholars observing the country: is there a process that can be called Alawization? By Alawization, we mean that the nomination of members of the Alawi community to positions of power across Syria is a political and economic manoeuvre, aiming to extend as much as possible the "Assad dynasty" (PINTO, 2013, p. 211) in the country. It is a new form of nepotism and clientelism, reinforcing the reins of power around the Assad family and the ones they judge are reliable. Ergo, Alawization is not connected to a sectarian view of the form in which politics is organized in the country, nor is it based on the assumption that the regime is religiously intolerant.

In that sense, this paper proposes to address the following questions which we treat as fundamentally interrelated, that is: how could Alawization have become a political process in Syria? How could this have evolved over time? And how is it perceived among practitioners of international relations? The argument put forward is that although the Alawi's ascension to power is a clearly identifiable phenom enon, the concept of Alawization is more perceived as an ongoing process rather than a well-established phenomenon. Eventhough as a processit is still not possible to understand how widespread it is, nor to correlate it to the deterioration of Syria's politics. It can be said as ongoing, because, although the nomination of Alawis to positions of power is not traceable at the moment, due to the civil war the country faces, there is still a sense of permanence of the Assad dynasty, allowing for Alawization to, thus, be used to maintain Bashar Al -Assad in power. Previous scholars (VAN DAM, 2017; 2011; ZISSER, 2001; WEDEEN, 2019; BATATU, 1999) have analysed the process of Alawis' rise to power in Syria and how power remains concentrated in the hands of this group. However, they have not named and problematized it fully within Syria's social and political sphere. Therefore, this paper's major contribution to the scholarship is to name this known process, and to investigate through international observers if it can be perceived as a historical representation of Syria's reality. 
To aid in the development of this new concept, we bring the perception of international relations' practitioners about Alawization to the table, since it allows us to test the validity of this concept with a relevant group. To answer our above stated research questions, our methodology is based on historical representations and the need to bring perception in order to understand reality - or at least, a representation of it - over time, and with that, to be able to unravel the hypothesis madehere (DUNN, 2008). In that sense, our methods include semi-structured interviews with diplomats based at the United Nations (UN) working with Middle Eastern issues and/or those that have already been a ssigned to posts in Syria, and the secondary analysis of both quantitative and qualitative data already gathered and published by scholars researching the rise of Alawis in Syria (as a way of crossing information and checking if, in the literature, whatwe gathered through the interviews have meaning). It is important to add that, although the number of interviews is limited and it will not account for a clear international perception, the task of bringing such a perspective is importantfor the method chosen: the one of historical representation and how it depends on the use of perception.

This paper is divided as follows: first, it will measure Alawization through the establishment of important events in Syria's history and also of some criteria that will help indicate how accurate representation Alawization is at such events. Then, it will engage with the relevant academic literature on the subject presenting data about the Alawi community and regarding Alawis that began to occupy key positions in the regime and militaryforces after the rise of Hafiz al-Assad. This section aims to trace the conditions that could allow for Alawization to take place, and if such a process developed over time, becoming a constitutive element of the deterioration of the regime's legitimacy. Then, we will introduce our findings on perception through the analyses of interviews conducted with practitioners of international relations., Their perceptions contribute by providing a fresh insight into the subject and help to validate (or not) the development of the concept offering the literature a nuanced analysis about Syria's internal dynamics.

\section{Measuring Alawization}

Alawization, as was established, is a concept that defines a process happening in Syria in which, through the nomination of Alawis to positions of power across the different sectors of society and by improving, through clientelist and nepotistic means, the situation of the regions inhabited primarilyby Alawis - the Assad dynasty finds a way to prolong its power. With that in mind, how, then, can we measure Alawization? As a subjective concept describing a subjective framework, there are some criteria we need to put in place in order to assess the viability of the concept as a representation of Syria's reality.

First and foremost, there are some events in Syria's history which are pinpointed to be analyzed - understanding that in those moments, Alawization could have been in evidence. These events are: the colonial period; the rise of Ba'ath to power; the Corrective Revolution that led Hafiz Al-Assad to power; and finally, the transition of power to Hafiz's son, Bashar Al-Assad. We select these events as we understand that theyare, in Syria's history, moments in which rather Alawis were evident or the Assad dynasty played an important role - and where investigation on the strategies they used to play such an important role, as, possibly, Alawization, must be investigated. The demarcation of time of the paper goes up to the transition of power to Bashar Al-Assad, as we understand that this moment shows the continuity of the Assad dynasty - and how the process of Alawization was made present then. We understand the importance of continuing to check if Alawization is a proper concept to represent Syria's reality, especially considering the significant political,economic, social and demographic shifts the country has been experiencing over the last decade with the civil war. However, our goal here is not to analyze this moment, but to, first, test the validity of this concept through the perception of international practitioners and as a historical representation.

With that in mind, understanding the colonial period is important, since the French mandate divided the country along ethnic lines, contributing to the deterioration of internal relations between the groups. This is the first event that will be elucidated in the next section and the first criteria considered. 
Regarding the rise of Ba'ath to power and the Corrective Revolution, the criteria analyzed will be the quantity of Alawis occupying both strategic positions and as officers in the armed forces (when this information is made available), the importance of the role they played and for how long they stayed in power. Finally, the criteria analyzed during the transition of power from Hafiz to Bashar will be on the steps necessary for such a transition to really happen. Did this transition attend the legislation? The next section will extensively present, withregards to the literature, these criteria and the development of the concept of Alawization as a historical representation of Syria.

\section{Does Alawis in power mean Alawization?}

As was observed, the circumstances that allowed Alawis to reach important positions in Syria are imprinted in its historical development, ever since the French mandate, when the country was divided across ethnical and religious lines, making domination easier. As a result, sentiments of distrust between minorities and the Sunni majority grew stronger after the country's independence. This then led to the rise of the Ba'ath party, a party dominated by minorities, especiallyAlawis.

It was during the Corrective Revolution of Hafiz al-Assad, in 1970, that Alawis, due to their close ties with the President started dominating the large majority of positions in the regime and occupied strategic posts both within the government and the armed forces. With the improvement of the Latakia region (the traditional homeland of Alawis) and the incentive offered to Alawis to seek higher education abroad, it was between the 80s and 90s that Alawis started prevailing in the different sectors and cadres of society (VAN DAM, 2011). During the second infitah ${ }^{\text {r }}$ of the late 80 s they were also the ones with the highest purchasing power and with capital to monopolize large sections of the Syrian economy. This practice carried on with the rise of Hafiz's son, Bashar al-Assad, to power in 2000.

Although the specific word "Alawization" has seldom been used by scholars working with Middle Eastern politics, the literature on this process is vast. It is possible to find authors that acknowledge the nomination of Alawis to positions of power as a pervasive phenomenon in Syrian society and discuss it through various lenses, mainly describing it as a demographic, sectarian or political phenomenon. A proper concept, however, was not coined before (see YASSIN KASSAB; AL-SHAMI, 2016;VAN DAM, 2017; 2011; ZISSER, 2001; BATATU,1999).

The colonial period is the first moment where we can observe the seeds of Alawization, due to the fragmentation of territory promoted by France and other European colonizers. With the Sykes -Picot Agreement, the Middle East previously occupied by the Ottoman Empire - was divided between the United Kingdom and France (LESCH, 2019). The French did not contribute to the formation of local administrative institutions that would prepare the population for independence. Instead, their control in 1920 came through the expulsion of local rulers and through the deployment of a large military contingent and a new hierarchy of French civil administrators-leaving little room for local politicians to act and ensuring the extension of French domination (CLEVELAND; BUNTON, 2009).

By dividing the territory along regional and ethnic lines, "emphasizing communal differences and aspirations, the French claimed to be bowing to political reality and popular desire” (KHOURY, 1987, p. 58). What ensued, however, was the adoption of a "divide and rule" strategy, where the division of the territory was a form of weakening pan-Arab ideologies through the reinforcement of ethnic ones. In that sense, the principles that could instigate cohesion and organization among the several and diverse ethnic groups within Syria were neutralized through an emphasis on that which made them different (LESCH, 2019).

\footnotetext{
Infitah' became known as an 'open door' policy or a policy of economic liberalization that spread throughout the Middle East in the 80s and 90 s, influenced by the Washington Consensus. These were neoliberal policies of stabilization and structural adjustment through the loosening of economic controls and encouragement of the private sector to overcome the financial and economic crisis plaguing the region. Thus, it reflected a partial withdrawal of the state from its role as entrepreneur and provider of social welfare for the population (BEININ, 2009; PERTHES, 1994; SUKKAR, 1994).
} 
Michael Provence (2005) illustrates the division of the territory, presenting three partitions: the Syrian State, which included Damascus and Aleppo; the Alawi State, located in the mountains around the region of Latakia; and the Druze State, located in the south of the present country. With this disintegration, the French objective was to emphasize the social and political divisions, facilitating domination and reducing the possibilities of insurgency. To ensure that society remained divided, colonial politics favoured traditional elites and the countryside, rather than those with modern education and who lived in cities. That was because new city elites, with Western education, leaned towards the nationalist, democratic, and socialist ideals. They were the groups responsible for the emergence of Arab nationalistideals. In that sense, it was at this moment that Alawis started to gain positions in the military force - outnumbering other ethnic or religious groups (LESCH, 2019; HOURANI, 2005).

Hence, "the destructive political instability that came to characterize Syria after independence in 1946 can be traced in part to the institutionalized fragmentation practised by the French mandate authorities" (CLEVELAND; BUNTON, 2009, p. 222). Also, it is at this moment that sentiments of distrust between minorities and the majority Sunnis population, which became the rulers after Syria's independence, became stronger. These sentiments, along with a growing and extreme inequality among minorities - constituted mostly of peasants - and the majority Sunni urban elite, led to the radicalization of the army. The army ranks were mainly composed of peasants who tried to obtain a better life than what was available in the countryside, thus making it possible to foster a base of support for the creation and strengthening of the Ba'ath party. The party provided new leadership and organized power, which attracted the new middle classes and peasants into the struggle against the old regime (LESCH, 2019; YASSIN-KASSAB; AL-SHAMI, 2016; ZISSER, 2002; HINNEBUSCH, 1990).

The ascendance of the Ba'ath party to power in 1963 dethroned Syria's traditional authority and promoted a complete alteration of its entire pre-established social pyramid, bringing a broad coalition of political and social forces that had long been neglected to power. In 1970, due to growing disagreements inside the Ba'ath party, the Corrective Revolution brought Hafiz al-Assad to power. From that moment on, the Assad dynasty began. The regime uses mechanisms, such as clientelism and patronage , in order to remain in power continuously - mechanisms that are considered part of the process of Alawization.

The system characterizing Assad's regime is an authoritarian one, with centralized political power and where the military and state bureaucracy play a dominant role. In addition, there is a parochial government practice, imprinted through the use of political interests for the benefit of clientelist networks - where personal ties and loyalty have great importance. Regarding the key groups that have the greatest privileges, it is possible to see the formation of a coalition of people who benefit from the patronage and clientelist characteristics of the regime.

Members of this elite reached the top thanks to one of the following four types of links to Asad: (1) family connections: e.g. his brothers or sons; (2) tribal or communal ties - belonging to the Asad's tribe, Kalbiya, or his community, the Alawis; (3) ties of personal friendship to Asad's circle of friends who shared his thinking and approach, some of whom had been his companions since the 1950 s and ' 60 s - the formative years of his journey to the top; and (4) occupational ties, being one of Asad's assistants and advisers, people who had long worked closely with him (ZISSER, 2001, p. 30).

With the secured domination of the population through coercion and the clientelist relations based on the benefits granted to the coalition that shared ties with the ruler, Assad managed to ensure his survival in power and could guarantee greater privileges to the Alawis (DAGHER, 2019; VAN DAM, 2011; ZISSER, 2001). These benefits were embedded in various sectors. In general, the members of this community have improved their socioeconomic status with greater access to education and infrastructure. Some particular Alawis, those closer to Assad, were allocated in relevant positions in the army or the party itself.

The improvement of the socioeconomic conditions of this group can be seen when looking at the situation of the Latakia region - mostly Alawi. In 1970, only 10\% of households in Latakia had access to safe drinking water; 15 years 
later, the number was over 70\%. Roads had also been built for every village. When Hafiz w as in school, few individuals worked in the region's only industry - a tobacco company. By mid-1980s, 40,000 employees worked in public sector companies in food processing and in the manufacture of aluminium, cement, textiles, carpets, among other products. The port in Latakia City was expanded and the University of Tishreen was created, housing 15,000 studentsin 1985 - bringing new intellectual standards to the region. The Alawis became doctors, engineers, lawyers, and university professors, so that 25 years after Assad's rise of power, they were strongly represented across different sectors, rivalling and sometimes displacing the Sunnis occupying important positions (VAN DAM, 2011; SEALE, 1995).

Of course, ensuring the development of a region is not a bad thing for a President to do. The question being put here is that such an investment was made disproportionately in comparison to the socioeconomic development of other regions, which were not inhabited by Alawis. When compared to other regions, one notice s the difference: in the 70s, the western Ghab region, inhabited by Alawis, had between 34 and $41 \%$ of girls attending school. At the same time, in eastern Ghab, inhabited by Sunnis, the number ranged from zero to 7\%. Investment in education in the Latakia region meant that by 1977 there were $124 \%$ more students than in 1964 (SEALE, 1995; DRYSDALE, 1981).

As for the army, the changes started after the coup d'état that brought the Ba'ath party to power. Many army officers were fired, and $90 \%$ of those nominated to fill those vacancies were Alawis. Effectively, of the 700 officers dismissed, about half were replaced by Alawis (VAN DAM, 2011). In addition, as seen before, the leadership of the Ba'ath Military Committee was held by three Alawis: Muhammad 'Umran, commander of the 70th Brigade, the backbone of the Ba'athist military organization; Salah Jadid, chief of staff of the Syrian army; and Hafiz al -Assad, air force commander (VAN DAM, 2011). With the seizure of power in 1970, Hafiz put in place more measures to increase the number of members of his community holding political and military posts (WEDEEN, 2019). Having Alawis in these posts was in Assad's interest, since it guaranteed the execution of his plans for the country and allowed him to maintain power more easily. Examples of these nominations of Alawis by Hafiz to occupy important positions go beyond the family ties that include his five brothers, Rif'at al-Assadbeing the most notorious, and both of his sons, Basil al -Assad, until his death on 1994, and Bashar al-Assad, wholater took over the presidency after his death.

Alawis also occupied positions in military intelligence and as commanders of the different armed forces. 'Ali Duba was nominated head of military intelligence and later promoted to adviser of the president. Muhammad al-Khuly was appointed by Assad as head of intelligence for the air force, and he played a role in the Rif'at's attempt to seize power. ${ }^{2}$ In addition, Ali Haydar, Special Forces Chief, also had ties to the president and was one of the generals sent by Assad to confront Rif'at. Another Alawi for whom Assad provided benefits was 'Adnan Makhlouf, cousin of Hafiz's wife, chosen to be commander of the President's guard after holding offices in the Air Force (DAGHER, 2019; BATATU, 1999; SEALE, 1995). According to Hanna Batatu (1999, p. 217), “out of the thirty-one officers whom Assad handpicked between 1970 and 1997 as chief figures in the armed forces, the elite military formations, and the apparatuses of security and intelligence, no fewer than nineteen or 61.3 percent have been Alawis”. Moreover, during those 27 years, the individuals who remained the longest and in the most important positions were not only Alawis but were also part of the same familyor tribe as Assad the Kalbiyyah. Among the other tribes, a notably large share of positions ( $21 \%$ of the total Alawis taking positions) came from the Haddadin, the tribe to which Hafiz's wife belonged (BATATU,1999). Assad's marriage to Anisa was also a political

\footnotetext{
2 The relationship between Hafiz and his brother, Rif'at, was not an affectionate one. In 1983, President Hafiz Al-Assad became seriously ill and the issue of his succession became acute among members of the government. The president indicated that a six-man committee beformed - and did not consider inserting his brother in it, due to his reckless and notoriously corrupt characteristics. Afraid of the president's possible death, and the consequences it could bring, the Alawi generals turned to Rif'at for leadership. Rif'at interpreted the sudden support of the Alawi generals as a blind loyalty to his leadership, so he began to preparefor seizing the power believing that, should this scenario happen, the generals would continue to show their support. In the meantime, however, Hafiz Al-Assad showed signs of recovery, causing the Alawi generals to turn their attention to him and forget the support they had given to Rif'at - even considering him a possible threat. Hafiz, once recovered, ordered Rif'at to be kept under surveillance, while he clung to the power he still had. After a final attempt by Rif'at to take power in 1984, President Hafiz Al-Assad got personally involved and, in 1985, ordered his brother's exile (VAN DAM, 2017; ZISSER, 2001).
} 
act as it provided a strengthening of relations with the Makhlouf family, an important one in the village that helped boost Hafiz's status (DAGHER, 2019; ZISSER, 2001).

It is also possible to point out that among the 31 officers handpicked by Assad, 11 were Sunnis. But looking at this information more carefully, we can see that most of them did not act on their posts at the same time, reducing the number of Sunni officials at any given time dramatically. In addition, Mustafa Talas, Hikmat al -Shihabi and NajiJamil, for example, are some of the Sunnis who either held unimportant positions or who, over time, lost Assad's confidence and were removed from their posts (BATATU,1999). Thus, non-Alawi officers could hold senior military posts, as long as they held positions that posed no real threat to the President, or where his Alawi supporters could act to dissipate any sign of insurrection.

Major General Naji Jamil, for example, even while commanding the air forces, could never use them against the president because the main air bases were run by Alawi government supporters. On the other hand, Major General Mustafa Talas, as soon as Bashar came into power, was stripped down of power as Minister of Defense, as part of an "authoritarian upgrading” (HINNEBUSCH, 2012), or a replacement of an ageing autocratic structure to a new network of technocrats (VAN DAM, 2011). These officers could then exercise some power as long as it was in accordance with the President's policies. If there were any sign of deviation, they could easily be removed from their positions by their Alawi colleaguesor others who were better suited for the job. In fact, the appointment of Sunni officers to such high military positions, "could very well have been done with the idea of placating the Sunnis and dispelling the impression that the most important posts were exclusively held by Alawi” (VAN DAM, 2011, p. 69).

On the other hand, not all Sunnis posed threats to the regime. Some of them, who had been peasants, were also neglected by the Sunni elite before the Ba'ath Party's rise, and thus shared the same ideals as Assad. These individuals became friends with the President and accompanied him since the beginning of his political career. This means that close ties between the nominated person and the President sometimes is what matters most, even if they are not Alawis. They can be fitted in the third or fourth category presented previously by Eyal Zisser (2001) of people who share ties with the president and form a clientelist coalition benefitting of the privileges the President grants. Examples are the Sunnis 'Abd al-Halin Khaddam, who served as Vice President and Minister of Foreign Affairs between 1984 and 2004, when he resigned, or Mustafa Talas, Minister of Defense from 1972 to 2004. The nomination of Sunnis to positions of power in Syria, thus, does not undermine the validity of the concept of Alawization, since these were also forms of nepotism and clientelism of the government of Assad (both father and son), in order to secure the Assad dynasty(LESCH, 2019; DAGHER, 2019).

With Bashar al-Assad, the nomination of Alawis into positions of power remained, especially the ones from the same family or tribe as Bashar. Maher al-Assad, Bashar's younger brother, was an important piece in the armed forces and "his maternal cousins the Makhloufs were assuming prominent roles in the army, mukhabarat [Syria's secret police], and business, and were eager to demonstrate loyalty to Bashar" (DAGHER, 2019, p. 84). He also "gave even more key security positions to members of the Alawi community than his father had" (PHILLIPS, 2020), taking Alawization to a deeper level and ensuring that the power remained in his hands.

In Syria, we can observe that there was a formal system of governance on the surface with a constitution, institutions, popular organizations, professional associations, etc. This helped to create a sense of legitimacy and legality for the regime's actions. In this formal governance system there was, somewhat, representativeness and diversity in the occupied seats, since $60 \%$ of regime ministers and delegates to the People's Assembly or the Party Congress were Sunnis (which corresponds to almost $69 \%$ of the population). By contrast, there was a hidden face to the state, or an informal system of governance, consisting of the heads of security services and military commanders. It is this informal system that provided the real balance of power among the Assad coalition forces, as it was dominated by 90\% Alawis (VAN DAM, 2011; ZISSER, 2001). This informal government can be perceived extensivelyin the transition of power to Bashar al-Assad. 
Bashar al-Asad was parachuted on to the top of the regime in 2000 to prevent disunity among the officers and supporters of the late President Hafiz al-Asad. Faruq al-Shar', Syrian Minister of Foreign Affairs in 2000, has recounted in his memoirs that Minister of Defence Mustafa Talas, on the day of the death of President Hafiz al-Asad, proposed that al-Shar' should be given the task to directly prepare for a change in the constitution that would enable Bashar al-Asad to become the new president at the age of 34 instead of 40, as was laid down in the constitution (VAN DAM, 2017, p. 84).

Later on, as part of the "authoritarian upgrading" it was seen as a necessity to dismiss all Sunnis who held important positions to give full control of the regime to Bashar, even if they had strong ties with the President. Thus, Hikmat al-Shihabi, the Chief of Staff, was forcibly retired. 'Abd al-Halin Khaddam, Hafiz's close friend, was stripped of much of his authority as Foreign Minister, and Mustafa Talas was replaced as Minister of Defense. Since they were perceived primarily as Sunnis, they were viewed as a threat to the continuation of the process of Alawization with Bashar (VAN DAM, 2011; ZISSER, 2001).

In the economic sector, with the deepening of economic liberalization in Syria in the 90 s, influenced by the politics of the Washington Consensus, business leaders and corporations began to take part in the economy of the country. This capitalist elite that made up the urban middle class came mostly from the Sunni elite that previously controlled the country and was replaced by the Ba' ath party. With Hafiz in power, there was a limited and controlled reintegration of this Sunni urban middle class into the economy. Later on, in the 90 s, economic openness was greater, and this elite now included Alawis that two decades earlier received educational incentives from the regime. These new Sunni and Alawi elites became allies of Assad, taking hold of a considerable portion of the country's economic power, but remained on the margins of the central political coalition still dominated almost exclusivelyby Alawis. (ZISSER, 2001).

Between 1993 and 1994,112 of Syria's 171 largest corporations were state -owned, representing 70\% of Syria's companies (BRICAULT, 1993). Even though such companies were owned by the state of Syria and not by the Alawis itself, Alawization is made present in the economic sector as a form of the grasp of power the regime attempted in the different cadres of society. Such a strategy pays off when we realize that around 25 years after Hafiz's rise to power, $70 \%$ of the companies were controlled by the state. Around 25 years after that, the State is still controlled by Alawis with the rise of Hafiz's son, Bashar.

Apart from the state-owned companies, it was still possible to see Alawis thrive in the economic sector, as was the case of the Arab Syrian Company for Touristic Establishments (ASCTE), founded by the Alawi 'Uthman al -'A'idi in Damascus, a company that is specialized in networks such as Cham Palace Hotels and other tourism chains. The group owns around 17 hotels and tourism establishments and comprises 10 subsidiaries focused on tourism management, construction, engineering, maintenance, marketing, and transportation. Another company that enjoyed a monopoly in its respective field is TRANSTOUR, which specializes in car rental for pilgrims to Mecca (PÖLLING, 1994).

With Bashar in power, the grasp of Alawis in the economic sector was preserved and even enhanced, as family members who already had high posts in the bureaucracy or the military, migrated to the private sector without any obstacle. That is the case of Rami Makhlouf, Bashar's cousin since, as Dagher (2019, p.129-130) affirms, "it was clear that Bashar's cousin Rami and the Makhloufs were going to play a central role in Bashar's plans for the economy". He became responsible for controlling Syria's largesttelecommunications company, SyriaTel. His family, the Makhloufs, were owners of several duty-free shops across Syria's airports, and their family companies bid on every government construction contract, ensuring as many licenses as possible. This overlapping between the families and Syria's economy also takes place with Assad's younger brother, Maher. Apart from being officially an officer in the army's Fourth Division and unofficially a so-called supervisor of the army's elite units, he also cultivated a network of businessmen in the cigarette market, media and advertising, as well as government taking advantage of government contracts - supplying computers to schools, for example (DAGHER, 2019). 
The major transformation and entry into the leagues, so to speak, came in late 2006 , when the Assads and the Makhloufs established their own business cartel, a private holding company called Cham (...). Through a complex network of new companies and joint ventures as well as offshores shells and fronts, Cham became involved in every sector of the economy, including aviation, banking, consumer products, manufacturing, oil and gas, real-estate development, retail, and tourism (DAGHER, 2019, p. 130).

As it could be seen, the practice of bringing Alawis into positions of power across Syria is a widespread process, recognized by the academic literature, but which has never been named or defined before. So far, this paper aimed at shedding light onto this dynamic and attempting to reveal its internal nuances. In the section that follows, in order to investigate the accuracy of Alawization as a concept and check its validity as a representation of Syria's socio-political fabric, we present the results of the interviews conducted with diplomats and policy-makers with experience in Syria.

\section{Investigating perception throughinterviews}

Perception consists of the different responses that individuals present to events, as well as their aspects and attributes. In many ways, perception can be considered as an experience (PEACOCKE,2015; SIEGEL; SILINS, 2015), since it is based on beliefs, personalities and emotions of oneself (LEVY, 2013). Herrmann (2013, p. 335), in that sense, claims that "to understand how decisions were made (...) more attention needed to be paid to how people perceived the situations they faced and the instrumental assumptions they held (...)". Recognizing these perceptions, for Simon (1985), is more important than trying to comprehend how people balance the benefits and the costs for every decision they make.

Along these lines, and considering that the perceptions gathered by practitioners of international relations regarding the concept of Alawization is central in this study, we understand that the method of historical representations is fundamental, since it is through this method that we perceive how an object of inquiry (Alawization, for instance) has represented the Syrian reality over time (DUNN, 2008). For Dunn (2008, p. 79), “reality' is unknowable outside human perception, and there is never one authority on a given subject". This means that reality in itself, the essence of it, is impalpable and fluid, it is not cartesian and, so, we must comprehend it through representations and interpretations -or perceptions.

With that in mind, it is possible to note that Alawization, to define a process in Syria, is a subjective concept. For it to be brought up into the literature and to add to the knowledge of Syrian politics, it depends on the analysis of empirical data and, moreover, on the perception of relevant actors. The result of this investigation is a historical representation, following the development of the process of Alawization through the years. Is it, precisely, for this reason that perception is so important for this task. As a new concept and as a representation of reality, Alawization must be tested among a group with relevant opinions, to be perceived as a valid concept and as a valid historical and current representation.

Moreover, since the concept of Alawization involves working with notions of identities being constructed and highlighted in Syrian society and how Syrian leadership constructs its agenda based on the relationship they establish with certain groups within the population, constructivism is a central theoretical pill ar of this paper. "Constructivism (...) emphasizes the social and relational construction of what states are and what they want" (HURD, 2008, p. 299). In a narrower sense, national interest can be understood through a standpoint focused on the relations the governments establish, rather than the norms and rules they must follow. This means that, for the Syrian case, even more important than the rules the regime has to follow, are the connections it builds with different groups, especially the ones who have links to the President (both Hafiz and Bashar).

Focusing on said relations is important because, as Friedrich V. Kratochwil (1989) shows, in a socially constructed world, agents are able to reproduce and change the structures through their practices and connections. Stated differently, through their actions they can demonstrate intentions or justify their choices. Alawization could thus be considered a self-constituting practice of the regime, which has effects on how Syrian social and governmental structures are organized. 
For the purpose of uncovering the perception of the concept of Alawization, the method of semi-structured interviews with diplomats from different nationalities (Brazilians, Saudis, Iranians, and Syrians) was put into practice. Indeed, diplomats do not have formal authority to make foreign policy decisions. However, investigating their perceptions is a valuable alternative, especially considering that they are practitioners of international relations linked to the foreign policy processes, providing us with relevant understandings of their country's foreign policy when compared with those of the general public.

Five non-structured interviews were carried out at the United Nations' headquarters in New York with diplomats who were assigned to posts at their respective countries' Permanent Missions to the UN. Two non-structured interviews were carried out via telephone with a Brazilian diplomat, Thomaz Alexandre Mayer Napoleão, Second Secretary serving at the Brazilian Embassy in Moscow, and Antonio de Aguiar Patriota, then Brazilian Ambassador to Italy and former Brazilian Minister of Foreign Affairs (between 2011 and 2013). Both had previously had posts at the Brazilian Permanent Missions to the UN and have experience in Middle East affairs. This diplomat sample was reached through a chain-referral sampling.

We understand the limits of a methodology that counts on only seven interviews. But we also recognize that this limited number of respondents, however small, has made a significant contribution to the progress of the research. It is worth noticing that we do not rely on only that research technique to make our point, but combine these interviews with the investigation of the literature and the choice of historical representation as our method. We do not wish to affirm that the perception of these diplomats represents the perception of their countries as a whole, but their words represent a chance to have a valuable glimpse of what international relations practitioners working on the Syrian issue are thinking about the internal Syrian affairs. This will also, hopefully, help scholars in the construction of a wider internationally oriented understanding of Syrian politics and society.

Syria was the first diplomatic mission contacted, but it was not receptive to the idea of giving an interview. Two diplomats from Saudi Arabia, who were approached at a meeting at the UN, agreed to an interview. Speaking with Iranians diplomats was a priority from the beginning, due to their presence in Syria as one of Ass ad's closest allies.

After getting in touch with the Diplomatic Mission of Iran, the Iranian Minister of Political Affairs to the UN who led the team of diplomats responsible for covering these topics at the Security Council, including ones related to Syr ia, agreed to give an interview and also pointed out two other colleagues that could collaborate for the project. They both considered themselves as researchers in addition to their occupations as diplomats.

The choice to interview Brazilian diplomats, although it may seem unorthodox at first, was made because they could present a different perspective on the subject, being geographically distant from Syria's political neighbourhood. Also, Brazil has been impacted by recentevents in Syria, receiving around 3,326 refugees, in 2018, a number that comprises $40 \%$ of the country's refugees (CONARE, 2018).

Questions were formulated in a non-structured manner to ascertain diplomats' opinions and use their testimonials qualitatively. The open-ended questions used as an interview guide were:

1) Do you think that there is a phenomenon that can be called "Alawization" in Syria? As in, doyou believe Alawis have more access to economic and political power in Syria?; and

2) If so, when do you think this process started to take place?

The diplomats referred to throughout this article are listed in Table 1 below. As most of them chose to sign a non-identity identification form, the table makesit easier to keep track of each diplomats' nationality.

Overall, the answers to these questions were diverse and wide-ranging. The former Brazilian Ambassador to Italy, now Ambassador in Egypt, Antonio Patriota, argued that the concept of Alawization in Syria should not be considered in the sectarian sense, or as he put it, in the "the Alawization of the non-Alawis", or the conversion of non-Alawis to the Alawi sect (PATRIOTA, interview2018). Notwithstanding, he said that the concept makes sense when it comes to pointing 
Alawis to key positions as a form of holding onto the reins of power. The Ambassador could not pinpoint the moment in which this dynamic became visible, but he explains that the Syrian Ba'ath party did not have many regional allies, especially when it came to the "extremist Saudi ideology", the Wahhabism ${ }^{3}$ in Saudi Arabia that saw the secular Syrian regime with mistrust. For Patriota, given the upheaval seen during the last 15 years ${ }^{4}$ in the region, kinships started to flourish around religious traditions or common enemies. In that sense, it could be possible to conside r Alawization as part of a process of shifting foreign alliances.

Table 1 - List of Diplomats Interviewed

\begin{tabular}{ll}
\hline Diplomat & Date of Interview \\
\hline Antonio Patriota (Brazilian) & 19 April 2018 \\
Thomaz Napoleão (Brazilian) & 21 March 2018 \\
Saudi Diplomat A & 30 April 2018 \\
Saudi Diplomat B & 21 March 2018 \\
Iranian Minister of Political Affairs & 21 March 2018 \\
Iranian Diplomat A & 28 March 2018 \\
Iranian Diplomat B & 19 April 2018 \\
\hline Source: Elaborated by authors (2020) &
\end{tabular}

Source: Elaborated by authors (2020)

Likewise, Brazil's Second Secretary serving at the Moscow Embassy, Thomaz Alexandre Napoleão, agrees that if Alawization means that Alawis in power bring others to the intelligence services and the Ministries then that process is real. Napoleão says that there is a concession of privileges to the Alawis from those in power, and identifies the rise of Hafiz al-Assad to power as the start of this process (NAPOLEÃO, interview, 2018).

In that sense, it is possible to note that both Brazilian diplomats tend to mention the sectarian view of the concept, in order to deny it. But when analysing it through a political and economic lens - the same one the paper pinpoints as central -, they seem to agree that there is an actual preponderance of Alawis in positions of power in Syria. Napoleão even uses the word "privilege" to describe it.

When the same questions were posed to Iranian and Saudi diplomats, it is possible to see a clear difference in their answers - which is expected, since it goes along with their countries positioning regionally. The Saudi diplomats interpreted the concept in a sectarian sense. Both Saudi Diplomats A and B seemed to understand Alawization as an intolerance towards non-Alawis by the Alawis in power, leading to, sometimes, even persecution or massacres. Such practice, for the diplomats, becomes more present during the current conflict in Syria. The former claims that the conflict is sectarian but pinpoints the start of Alawization with the rise to power of Hafiz al -Assad (Saudi Diplomat A, interview, 2018). Saudi Diplomat B, on the other hand, believes that this phenomenon started with the Arab Spring and that it has become stronger with the Iranian influence (Saudi Diplomat B, interview, 2018).

Juxtaposing these responses with the ones provided by the three Iranian diplomats we interviewed, one can observe vast differences in their opinions. The Iranian diplomats stated that there is no Alawization happening in Syria. Iranian Diplomat A, for example, justifies that there is an increase of Alawis' influence because of the main political family in Syria, but that this does not mean that this phenomenon has any political significance since other minorities in government were also included besides Alawis (Iranian Diplomat A, interview, 2018). Again, sectarianism plays a part, and Iranian Diplomat A affirms that, "the system is not religious, it is a secular system (...). If they [the Assad family] want to

\footnotetext{
3 “'Wahhabism' generally refers to a movement that seeks to purify the Islamic religion of any innovations or practices that deviate from the (...) teachings of the Prophet Muhammad (...). In the West, the term has been used mostly to denote the form of Islam practiced in Saudi Arabia"(BLANCHARD 2007, p. 1).

4 Here, Patriota refers to the Iraq War in 2003 and the destabilization that emerged in the region afterwards - which for him creates ground for the emergence of ISIS.
} 
increase the role of others, they will undermine themselves; that is why they are secular". The diplomat seemed to imply that Alawization in a sectarian sense is not possible since Assad's regime does not have the power or the willingness to change people's identities.

The Iranian Minister of Political Affairs to the United Nations following the same rationale, declared that the political system in Syria is secular (Iranian Minister of Political Affairs to the United Nations, interview, 2018). People might be Muslim, he claimed, but that does not cross -over into government structures, “they are Alawis but that doesn't affect the relations". The Minister also analysed the shift of power from Hafiz to Bashar neither as an enhancement of Alawization, nor as a cause for changing socio-political relations inside Syria or regionally. Instead, he understood it as a mere change in circumstances.

Finally, Iranian Diplomat B became more emphatic in the responses. The officer maintained that Alawis do not reign in Syria and that they are not in power. "This is a wrong impression, that since the President is Alawi the whole system is Alawi” (Iranian DiplomatB, interview, 2018). Iranian Diplomat B stated that it is the Ba'ath party that rules Syria, and it was a Christian who created it. The rise of Hafiz al-Assad to power was not because he was Alawi, "it was because of his competence". He went on to claim that Hafiz's ascendancy to the presidency was due to the "powerful performance" he played within the Ba'ath party. For the diplomat, most cabinet-level positions in Syria - Minister of Interior, Minister of Foreign Affairs, Minister of Defence - are not occupied by Alawis, and if there was Alawization it would logically follow that these positions would be taken by Alawis. "There has never been a transition of the Alawis to power", and the officer believes that this will not be the case in the future either.

It is noticeable that the answers of these diplomats can be grouped by their nationalities. Of course, it is expected that they would answer similarly, because of the position they hold inside their own countries. Nevertheless, what is interesting is that, even though during the interview the concept of Alawization was explained, diplomats manipulated it according to their - and their countries' - beliefs and positions. That, in no way, weakens the goal of the paper. On the contrary, it shows that there is, in fact, a process being perceived in Syria, but one in which the definition and understanding are yet to be elucidated.

\section{Conclusion}

This paper has analysed Alawization as a concept capable of explaining a multi-faceted process happening within Syria - one in which members of the Alawi community came to occupy strategic positions within the bure aucratic and security apparatus because of the ties they held with the Assad family. The conditions for the process of Alawization to become a political process in Syria were analyzed in different scenarios and considering different criteria. We discover that Alawization can be traced back to the colonial period, when France divided the territory along ethnical lines, aiming to weaken the insurgency of groups who sought independence. Besides that, Alawization has three central moments that contributed to its evolution: the rise of Ba'ath to power; the Corrective Revolution of 1970; and the transition of power to Hafiz's son, Bashar al-Assad in 2000.

The process of Alawization is perceived rather differently by international practitioners. For some - especially the Brazilian diplomats -, it is seen as a clearly defined and broad process, visible through the occupation of positions of power by Alawis resulting in impacts on Syrian politics. For diplomats who represent regional players, such as Saudi Arabia and Iran, the interpretation - although misconceived - tended to centre on religious issues and notions. This hints at the difficulty in developing and defining a new concept and shows that Alawization is a concept that still needs work in order to represent Syria's history.

On the other hand, looking at the literature, there seems to be a general agreement that the benefits granted to the Alawi sect is a process that can be termed Alawization. In attempting to combine such a literature to our respondents' answers, it is possible to arrive at the realization that Alawization is more perceived as an ongoing process rather than a 
well-established phenomenon, considering that Alawis represents about $12 \%$ of Syrian society, but $61 \%$ of all strategic positions and there is a sense of continuity of the Assad dynasty in Syria throughout the years. We therefore reached the conclusion that, although a limited concept, historical representation is not committed to portray reality itself - since for this method, reality, in fact, does not exist. In this sense, as a representation, arising from the perception of the diplomats and the data found in the literature, there is, indeed, a process that can be named "Alawization" in Syria. However, there is still disagreement on what this concept exactly means and how it impacts Syrian society and politics. Additionally, we still cannot measure how widespread this process is or its total impacts within Syria; more research is needed in those regards. Hopefully, this paper will instigate scholars studying Syria to dive deeper into the political significance of this concept and attempt to understand how politics, economics, and society interrelate in the making of the modern Syrian state.

\section{References}

BATATU, Hanna. Syria's peasantry, the descendants of its lesser rural notables, and their politics. New Jersey: Princeton University Press, 1999.

BEININ, Joel. Neo-liberal structural adjustment, political demobilization, and neo-authoritarianism in Egypt. In: GUAZZONA, Laura; PIOPPI, Daniela (Eds.). The Arab state and neo-liberal globalization: the restructuring of state power in the Middle East. Reading: Ithaca Press, 2009, p. 19-46.

BLANCHARD, Christopher. The Islamic traditions of Wahhabism and Salafiyya [online]. 2007. Available at: https://www.investigativeproject.org/documents/testimony/47.pdf. Accessed on: 10 June 2018.

BRICAULT, Giselle C. (Ed). Major companies of the Arab world 1993/94. London: Graham \& Trotman, 1993.

CLEVELAND, William L.; BUNTON, Martin. A history of the modern Middle East. New York: Westview Press, 2009.

Comitê Nacional Para Os Refugiados - CONARE (BR). Refúgio em números: $4^{\mathbf{a}}$ edição. Brasília. 2018. Available at: https://www.acnur.org/portugues/wp-content/uploads/2019/07/Refugio-em-nu\%CC\%81meros_versa\%CC\%83o-23-de-julho002.pdf. Accessed on 26 November 2019.

DAGHER, Sam. Assad or we burn the country: how one family's lust for power destroyed Syria. New York: Little, Brown and Company, 2019.

DRYSDALE, Alasdair. The regional equalization of health care and education in Syria since the Ba'thi revolution. International Journal of Middle East Studies, v. 13, n. 1, 1981, p. 93-111. Available at: https://www.cambridge.org/core/journals/international-journal-ofmiddle-east-studies/article/regional-equalization-of-health-care-and-education-in-syria-since-the-bathirevolution/AFA21352114FEA153AD95D6281CD32A6. Accessed on 06 March 2019.

DUNN, Kevin C. Historical representations. In:KLOTZ, Audie; PRAKASH, Deepa (Eds.). Qualitative methods in international relations: a pluralist guide. New York: Palgrave macmillan, 2008, p. 78-92.

FRIEDMAN, Yaron. The Nuṣayrī- ' Alawīs: An Introduction to the Religion, History and Identity of the Leading Minority in Syria. Leiden: Brill, 2010.

HERRMANN, Richard K.. Perceptions and image theory in international relations. In: HUDDY, Leonie; SEARS, David O.; LEVY, Jack S. (ed.). The Oxford handbook of political psychology. 2. ed. Oxford: Oxford University Press, 2013. p. 334-363.

HINNEBUSCH, Raymond A. Syria: from “authoritarian upgrading” to revolution? International Affairs, v. 88, n. 1, p. 95-113, Jan. 2012. Available at: https://www.jstor.org/stable/41428543. Accessed on 05 Sep. 2021.

HINNEBUSCH, Raymond A. Authoritarian power and State formation in Ba'athist Syria: army, party, and peasant. Boulder: Westview Press, 1990.

HOURANI, Albert Habib. O pensamento árabe na era liberal. Translated by Rosaura Eichenberg. São Paulo: Companhia das Letras, 2005.

HURD, Ian. Constructivism. In:SNIDAL, Duncan; REUS-SMIT, Christian (Eds.) The Oxford handbook of International Relations. New York: Oxford University Press, 2008, p. 298-316.

KHOURY, Philip Shukry. Syria and the French mandate: the politics of Arab nationalism, 1920-1945. New Jersey: Princeton University Press, 1987.

KRATOCHWIL, Friedrich V. Rules, norms, and decisions: on the conditions of practical and legal reasoning in International Relations and domestic affairs. Cambridge: Cambridge University Press, 1989. 
LESCH, David W. Syria: a modern history. Cambridge: Policy Press, 2019.

LEVY, Jack S.. Psychology and foreign policy decision-making. In: HUDDY, Leonie; SEARS, David O.; LEVY, Jack S. (ed.). The Oxford handbook of political psychology. 2. ed. Oxford: Oxford University Press, 2013. p. 301-333.

PEACOCKE, Christopher. Perception and the first person. In: MATTHEN, Mohan (Ed.). The Oxford handbook of philosophy of perception. Oxford: Oxford University Press, 2015.p. 168-180.

PERTHES, Volker. Stages of Economic and Political Liberalization. In: KIENLE, Eberhard (Ed.). Contemporary Syria: liberalization between Cold War and Cold Peace. London: British Academic Press, 1994, p. 44 -71.

PHILLIPS, Christopher. The battle for Syria: international rivalry in the new Middle East. London: Yale University Press, 2020.

PINTO, Paulo Gabriel Hilu. Syria. In: AMAR, Paul; PRASHAD, Vijay (Ed.). Dispatches from the Arab Spring: understanding the new middle east. Minneapolis: University of Minnesota Press, 2013. p. $204-242$.

PÖLLING, Sylvia. Investment law No. 10: which future for the private sector? In: KIENLE, Eberhard (Ed.). Contemporary Syria: liberalization between Cold War and Cold Peace. London: British Academic Press, 1994, p. 14 - 25.

PROVENCE, Michael. The great Syrian revolt: and the rise of Arab nationalism. Austin: University of Texas Press, 2005.

SEALE, Patrick. Assad of Syria: the struggle for the Middle East. London: University of California Press, 1995.

SIEGEL, Susanna;SILINS, Nicholas. The epistemology of perception. In: MATTHEN, Mohan (Ed.). The Oxford handbook of philosophy of perception. Oxford: Oxford University Press, 2015. p. 781-811.

SIMON, Herbert A.. Human nature in politics: the dialogue of psychology with political science. The American Political Science Review, v. 79, n. 2, p. 293-304,Jun.1985. Available at: https://www.jstor.org/stable/1956650?seq=1. Accessed on: 15 Dec. 2020.

VAN DAM, Nikolaos. Destroying a nation: the civil war in Syria. London: I.B. Tauris, 2017.

VAN DAM, Nikolaos. The struggle for power in Syria: politics and society under Assad and the Ba'ath party. New York: I.B. Tauris, 2011. WEDEEN, Lisa. Authoritarian Apprehensions: ideology, judgment, and mourning in Syria. Chicago: The University of Chicago Press, 2019.

YASSIN-KASSAB, Robin;AL-SHAMI, Leila. Burning country: Syrians in revolution and war. London: Pluto Press, 2016.

ZISSER, Eyal. The Syrian army on the domestic and external force. In: RUBIN, Barry; KEANEY, Thomas A. (Eds.). Armed forces in the Middle East: politics and strategy. London: Frank Cass Publishers, 2002,p.113-129.

ZISSER, Eyal. Assad's legacy: Syria in transition. New York: New York University Press, 2001.

\section{Interviews}

Antonio de Aguiar Patriota, 2018. Telephonic interview by author / Gabriela Santos da Silva. New York. 19 April.

Thomaz Alexandre Mayer Napoleão, 2018. Telephonic interview by author / Gabriela Santos da Silva. New York. 21 March.

Saudi Diplomat A, 2018. Personal interview by author / Gabriela Santos da Silva. New York. 30 April.

Saudi Diplomat B, 2018. Personal interview by author / Gabriela Santos da Silva. New York. 21 March.

Iranian Minister of Political Affairs, 2018. Personal interview by author / Gabriela Santos da Silva. New York. 21 March.

Iranian Diplomat A, 2018. Personal interview by author / Gabriela Santos da Silva. New York. 28 March.

Iranian Diplomat B, 2018. Personal interview by author / Gabriela Santos da Silva. New York. 19 April.

\begin{tabular}{ll}
\hline Authors' Contributor Roles & \\
\hline Gabriela Santos da Silva: & Conceptualization; Methodology; Data Curation; Project Administration; Visualization; Formal Analysis; Investigation; \\
& Writing (Original Draft Preparation); Writing (Review \& Editing); \\
Silvia Regina Ferabolli: & $\begin{array}{l}\text { Conceptualization; Methodology; Validation; Project Administration; Visualization; Investigation; Supervision; Writing } \\
\text { (Review \& Editing); }\end{array}$ \\
\hline
\end{tabular}

Information provided by the authors according to the Taxonomy of author contributions (CRediT) 